\title{
Use of Organo-Mineral Fertilizers in Grain Sorghum as Reverse Logistics of Organic Residues
}

\author{
Michelle Nunes Barcelos ${ }^{1}$, Reginaldo de Camargo ${ }^{1}$, Regina Maria Quintão Lana ${ }^{1}$, Uirá do Amaral ${ }^{2}$, \\ Leandro Coelho de Araujo $^{3}$, Marcelo Carvalho Minhoto Teixeira Filho ${ }^{3} \&$ Thiago Assis Rodrigues Nogueira ${ }^{3}$ \\ ${ }^{1}$ Institute of Agrarian Sciences, Federal University of Uberlândia, Uberlândia, MG, Brazil \\ ${ }^{2}$ Federal Institute of Education Science and Technology of Triângulo Mineiro, Advanced campus of Campina \\ Verde, Campina Verde, MG, Brazil \\ ${ }^{3}$ School of Engineering, São Paulo State University, Ilha Solteira, SP, Brazil \\ Correspondence: Michelle Nunes Barcelos, Institute of Agrarian Sciences, Federal University of Uberlândia, \\ MG, Brazil. Tel: 55-34-3412-2869. E-mail: michelleuems@gmail.com
}

Received: September 23, 2018

Accepted: November 5, $2018 \quad$ Online Published: January 15, 2019

doi:10.5539/jas.v11n2p435

URL: https://doi.org/10.5539/jas.v11n2p435

\begin{abstract}
Organo-mineral fertilizers are an opportunity for technological innovation, because allow the correct disposal of waste from various agroindustrial sectors, which is a global problem, in order to add value to the by-product generated, as prioritized in reverse logistics. In this sense, the objective of this work was to evaluate the effect of organic matter sources on the composition of organo-mineral fertilizers in relation to the exclusive use of mineral fertilizers in cultivation of grain sorghum. The experiment was carried out at the Experimental Farm of the Federal Institute of the Triângulo Mineiro, located in the municipality of Campina Verde, State of Minas Gerais, Brazil. The experimental design was a randomized block with eight treatments and four replications arranged in a $4 \times 2+2$ factorial scheme, corresponding to: four levels of organo-mineral fertilizers (70, 100, 130 and $160 \%$ of the recommended dose of phosphorus), two sources of organo-mineral fertilizers (sewage sludge and filter cake), and two controls (without and with recommended mineral fertilization). The evaluations were: height of stem, number of leaves and stem diameter at 30,60, and 90 days after sowing (DAS); total plant height; dry mass of plant shoot at $90 \mathrm{DAS}$, in vitro digestibility of organic matter at $90 \mathrm{DAS}$; the relationship of leaf area/ leaf and leaf area/ plant at 90 DAS. All parameters obtained a significant effect for the levels of organo-mineral fertilizer, independent of organic source, except to number of leaves and stem diameter. However, the relationship between the two organic sources was not significant just to plant height at 60 DAS. Interaction between fertilizer levels and organic source occurred to plant height at 90 DAS, dry mass per plant at 90 DAS and in vitro digestibility of organic matter. There was good adjustment in the quadratic regression equation for sorghum growth.
\end{abstract}

Keywords: Poaceae, recycling, organic fertilizers, plant nutrition, urban waste

\section{Introduction}

The sorghum (Sorghum bicolor (L.) Moench) is a native plant of northwest region of Africa, with tropical climate and short-day, belongs to the group of grasses (C4), has been cultivated in a wide range of latitude. It is tolerant to high temperatures and water deficiency, due to its leaf characteristics of xerophytic plants and efficient morphological mechanism (Andrade-Neto et al., 2010), which makes it cultivable in the summer season.

Organic compounds when available can promote the quality of soil and efficiency in the production of plants, because influence in its chemical, physical and biological attributes. Traditional agricultural practices to produce fertilizers from artisan blends, were improved with addition of NPK (Cruz et al., 2017). That brought an innovative agricultural input on production of organo-mineral fertilizers, which allow a greater use of available nutrients than conventional fertilizers.

Other potential benefits of organic matter added in fertilizer is the control of phytopathogens of soil. Tomazeli et al. (2011) observed the increase microbial activity of decomposing agents, there is a reduction number of survival structures of pathogen and this minimizes the symptoms of disease in plants caused by fungus 
Sclerotium rolfsii. Studies have demonstrated that sewage sludge applied to soil improved the emergence of seedlings and decreased the severity of Erysiphe diffusa (Araújo \& Bettiol, 2009).

Organo-mineral fertilizers are produced about association of organic matter and minerals in a balanced form, can be found commercially with diversifying source of organic raw material. The compost must be at least $8 \%$ of organic carbon; CEC of $80 \mathrm{mmol}_{\mathrm{c}} \mathrm{kg}^{-1} ; 10 \%$ of isolated primary macronutrients $(\mathrm{N}, \mathrm{P}, \mathrm{K})$ or in mixtures $(\mathrm{NP}, \mathrm{PK}$, NPK or NK); $5 \%$ of secondary and micronutrients maximum humidity of $30 \%$ (Trani et al., 2013).

In addition, there are several problems caused by inadequate management of solid wastes from urban, agricultural and industrial activities on the environment, resulting in serious economic and social damages, as in the aspect of costly spending on preventive measures and treatment of health (Schmidt-Filho et al., 2016). Sewage sludge mixed to mineral fertilizers is suitable for application to soil and can reduce the costs of its disposal (Kominko et al., 2017).

This evolution in the fertilizer sector based in reverse logistics, has become companies more competitive, with strategic use of their post-consumer products, financial return and proper environmental management (Teles et al., 2016). It also allows sustainable development by reducing the amount of stored waste, ensures the recycling of nutrients and organic matter to the soil and improves the use of natural resources, as long as it meets the minimum quality requirements (Kominko et al., 2018).

Therefore, the objective of this work was to evaluate the reuse of organic wastes filter cake and sewage sludge, previously transformed into organo-mineral fertilizer, in cultivation of sorghum.

\section{Methods}

A field experiment was carried out in the experimental farm of the Federal Institute of the Triângulo Mineiro

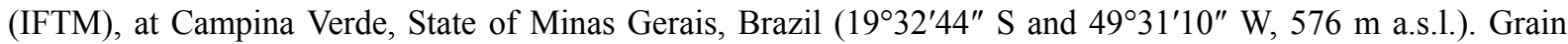
sorghum cultivar Enforcer was used as test plant and cropped in a Typic Hapludox (Soil Survey Staff, 2014) after limestone application (adding $1.35 \mathrm{Mg} \mathrm{ha}^{-1}$ of limestone) based on the soil test results (Table 1) and recommendations to sorghum plants of the State of Minas Gerais (Ribeiro et al., 1999).

Table 1. Chemical properties of soil in the experimental area before sorghum seeding

\begin{tabular}{lllllllllllll}
\hline Layer & $\mathrm{pH}$ & $\mathrm{P}_{\text {Mehlich-1 }}$ & $\mathrm{K}^{+}$ & $\mathrm{Ca}^{+2}$ & $\mathrm{Mg}^{+2}$ & $\mathrm{Al}^{+3}$ & $\mathrm{H}+\mathrm{Al}$ & $\mathrm{SB}^{1}$ & $\mathrm{CEC}_{\text {total }}{ }^{2}$ & $\mathrm{BS}^{3}$ & $\mathrm{~m}^{4}$ & $\mathrm{OM}^{5}$ \\
\hline $\mathrm{cm}$ & $\mathrm{H}_{2} \mathrm{O}$ & $\mathrm{mg} \mathrm{dm}{ }^{-3}$ & ---------------------- & $\mathrm{cmol}_{\mathrm{c}} \mathrm{dm}^{-3}------------------------$ & ----- & $\%$ & ----- & $\mathrm{dag} \mathrm{kg}^{-1}$ \\
$00-20$ & 5.4 & 26.0 & 0.19 & 1.2 & 0.4 & 0.2 & 3.40 & 1.79 & 5.19 & 34 & 8 & 0.8 \\
$20-40$ & 5.2 & 7.3 & 0.07 & 0.9 & 0.3 & 0.4 & 2.50 & 1.27 & 3.77 & 34 & 24 & 0.5
\end{tabular}

Note. Analysis were obtained according to procedures described by Embrapa (1997); ${ }^{1}$ SB: Sum of bases; ${ }^{2} \mathrm{CEC}_{\text {total }}$ : Cation exchange capacity; ${ }^{3} \mathrm{BS}$ : Base saturation; ${ }^{4} \mathrm{~m}=$ Aluminum saturation; ${ }^{5} \mathrm{OM}=$ Organic matter.

The experimental design was a randomized block with eight treatments and four replications arranged in a $4 \times 2$ +2 factorial scheme, corresponding to: four levels of fertilization with organo-mineral fertilizers $(70,100,130$ and $160 \%$ of the recommended dose of phosphorus), two sources of organo-mineral fertilizers (sewage sludge and filter cake) (Table 2), and two controls (without and with recommended mineral fertilization).

Table 2. Chemical characteristics of organo-mineral fertilizers composed of sewage sludge and filter cake

\begin{tabular}{|c|c|c|c|c|c|c|c|}
\hline Organic matter & $\mathrm{pH}_{\text {water }}$ & $\mathrm{OM}^{1}$ & $\mathrm{TOC}^{2}$ & $\mathrm{~N}_{\text {total }}$ & $\mathrm{P}_{2} \mathrm{O}_{5}$ & $\mathrm{~K}_{2} \mathrm{O}$ & Relation $\mathrm{C} / \mathrm{N}$ \\
\hline & & \multicolumn{2}{|c|}{-------- $\mathrm{g} \mathrm{kg}^{-1}$------- } & $\begin{array}{l}------ \\
\end{array}$ & ----0 & & \\
\hline Sewage sludge & 7.6 & 19.80 & 19.80 & 0.79 & 2.23 & 0.24 & $28 / 1$ \\
\hline Filter cake & 6.8 & 23.49 & 23.49 & 0.61 & 0.95 & 0.30 & $14 / 1$ \\
\hline
\end{tabular}

Note. ${ }^{1} \mathrm{OM}$ : Organic matter; ${ }^{2} \mathrm{TOC}$ : Total organic carbon.

The application of organo-mineral fertilizers was done manually in sowing furrow in march 2018 , in plots of $3 \times$ $3 \mathrm{~m}$ and spacing between rows of $0.7 \mathrm{~m}$. Nitrogen fertilization in coverage was made according recommendation to sorghum plants of the State of Minas Gerais (Ribeiro et al., 1999). Sprinkler irrigation after sowing up to seedling stage was realized so that the summer period, did not harm the establishment in the culture in the field. The control of weeds after sowing was by means of manual weeding between rows. 
After 30,60, and 90 days after sowing (DAS) was obtained the number of sheets, stem diameter and the plant height, in this, was considered the distance from the stem neck until sheath region of the last fully developed sheet. The total height was measured up to the apex of the panicle at 90 DAS.

The samples of aerial part of plants were packed in paper bags to drying in heater at temperature of $65{ }^{\circ} \mathrm{C}$ during 72 hours, and weighed in precision balance for determination of dry mass at 90 DAS. These samples were used to obtain in vitro digestibility of organic matter (IVDOM), which was determined using the methodology described by Tilley and Terry (1963).

The leaf area per sheet at 90 DAS was determined following the procedure of Pearce et al. (1975) and was calculated from Equation (1):

$$
\mathrm{LA} / \mathrm{S}=\mathrm{L} \times \mathrm{W} \times 0.75
$$

Where, LA/S $=$ leaf area per sheet $\left(\mathrm{cm}^{2}\right), \mathrm{L}=$ length $(\mathrm{cm}), \mathrm{W}=$ width $(\mathrm{cm})$.

The leaf area per plant at 90 DAS was determined following the procedure of Pearce et al. (1975) and was calculated from Equation (2):

$$
\mathrm{LA} / \mathrm{P}=\mathrm{LA} / \mathrm{S} \times 9.39
$$

Where, $\mathrm{LA} / \mathrm{P}=$ leaf area per plant $\left(\mathrm{cm}^{2}\right), \mathrm{LA} / \mathrm{S}=$ leaf area per sheet $\left(\mathrm{cm}^{2}\right)$.

The data were submitted to analysis of variance through the statistical program AGROESTAT (Barbosa \& Maldonado-Júnior, 2015) and means where significant were grouped according to Tukey's teste $(p<0.05)$, and in the existence of interaction the unfolding was obtained. Similary, the regression analysis was performed to verify the best doses of each organic source of all parameters of growth.

\section{Results and Discussion}

The analysis of variance showed a significant effect of levels of organo-mineral fertilization for variables plant height, leaf area, dry mass and in vitro digestibility of organic matter (Table 3). There was influence of sources of organic matter, except to plant height at 60 DAS. Regarding the additional control treatments, the mineral fertilization was better than the treatment without any fertilization, only to plant height at 90 DAS, total plant height and dry mass per plant (Table 3).

Doses of sewage sludge in corn demonstrated effect on plant height during entire cycle of culture and distinct behavior between the doses, however the characteristics of stem diameter and leaf area were not influenced (Costa et al., 2009). This was similar in this work, to both sources of fertilizer organo-mineral, sewage sludge and filter cake.

No effect of levels or sources of organo-mineral fertilizer were observed on the number of leaves and diameter of plants. There was not visible phytotoxic effect after the application of the organo-mineral fertilizer, maybe due to the heritability factor high magnitude for the characteristic (Araújo et al., 2014).

However, Silveira-Junior (2015) found phytotoxic effects soon after the application of bio-fertilizers, this obtained by anaerobic biodigestion of aviary bed on the Brachiaria brizantha cv. Piatã alone and consortium with fodder sorghum, which presented chlorosis and necrosis. 
Table 3. Mean and $F$ values for the plant phenotypic values on the basis of levels of organo-mineral fertilizers, source of organic matters and additional control treatments

\begin{tabular}{|c|c|c|c|c|c|c|c|c|}
\hline Treatment & PH30DAS & PH60DAS & PH90DAS & $\mathrm{TPH}$ & LAPS & LAPP & DMPP & IVDOM \\
\hline & \multicolumn{4}{|c|}{ 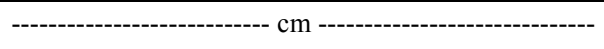 } & \multicolumn{2}{|c|}{-------- $\mathrm{cm}^{2}$--------- } & g per plant & $---\%$--- \\
\hline \multicolumn{9}{|c|}{ Levels of organo-mineral fertilizer ( $L O F)$} \\
\hline $70 \%$ & $16.09 \mathrm{a}$ & $31.47 \mathrm{a}$ & $45.22 \mathrm{a}$ & $67.50 \mathrm{~b}$ & $188.79 b$ & $1772.78 b$ & $26.13 b$ & $86.43 \mathrm{a}$ \\
\hline $100 \%$ & $16.28 \mathrm{a}$ & $31.60 \mathrm{a}$ & $46.93 a$ & $72.40 \mathrm{a}$ & $231.53 \mathrm{a}$ & $2174.07 \mathrm{a}$ & $28.66 \mathrm{ab}$ & $85.53 b$ \\
\hline $130 \%$ & $13.30 \mathrm{~b}$ & $27.23 b$ & $38.56 \mathrm{c}$ & $61.34 \mathrm{c}$ & $195.52 \mathrm{ab}$ & $1835.97 \mathrm{ab}$ & $30.33 \mathrm{a}$ & $86.27 \mathrm{a}$ \\
\hline $160 \%$ & $14.90 \mathrm{ab}$ & $29.12 \mathrm{ab}$ & $42.00 \mathrm{~b}$ & $69.13 \mathrm{ab}$ & $207.66 \mathrm{ab}$ & $1949.93 \mathrm{ab}$ & $30.25 \mathrm{a}$ & $86.46 a$ \\
\hline$F$-test & $7.91 * *$ & $4.18^{*}$ & $54.49 * *$ & $17.03 * *$ & $3.71 *$ & $3.71 *$ & $5.21 * *$ & $13.52 * *$ \\
\hline \multicolumn{9}{|l|}{ Organic matter (OM) } \\
\hline Sewage sludge & 14.52 & 29.06 & 40.92 & 65.67 & 193.54 & 1817.39 & 28.73 & 86.57 \\
\hline Filter cake & 15.76 & 30.65 & 45.43 & 69.51 & 218.20 & 2048.99 & 28.96 & 85.77 \\
\hline$F$-test & $6.39 *$ & $2.42^{\mathrm{NS}}$ & $81.36 * *$ & $11.69 * *$ & $6.38 *$ & $6.38^{*}$ & $7.87 * *$ & $45.38 * *$ \\
\hline \multicolumn{9}{|l|}{$L O F \times O M$} \\
\hline$F$-test & $1.33^{\mathrm{NS}}$ & $1.03^{\mathrm{NS}}$ & $4.01 *$ & $1.57^{\mathrm{NS}}$ & $2.15^{\mathrm{NS}}$ & $2.15^{\mathrm{NS}}$ & $32.97 * *$ & $34.38 * *$ \\
\hline \multicolumn{9}{|l|}{ Control treatments } \\
\hline Without fertilization & 12.51 & 24.89 & 34.88 & 56.81 & 151.65 & 1423.99 & 15.94 & 86.57 \\
\hline With mineral fertilization & 13.75 & 28.77 & 42.00 & 69.31 & 170.73 & 1603.18 & 23.15 & 86.70 \\
\hline$F$-test & $1.62^{\mathrm{NS}}$ & $3.64^{\mathrm{NS}}$ & $50.57 * *$ & $30.92 * *$ & $0.95^{\mathrm{NS}}$ & $0.96^{\mathrm{NS}}$ & $6.27 *$ & $0.30^{\mathrm{NS}}$ \\
\hline CV $(\%)$ & 9.35 & 9.85 & 3.35 & 4.76 & 14.02 & 14.02 & 8.05 & 0.39 \\
\hline
\end{tabular}

Note. Plant height at days after sowing (PH30DAS), (PH60DAS) and (PH90DAS) and total (TPH); leaf area per sheet (LAPS) and per plant (LAPP) at 90 DAS; dry mass per plant (DMPP) at 90 DAS; in vitro digestibility of organic matter $(\mathrm{IVDOM})$ at $90 \mathrm{DAS}$; LOF $\times$ OM: effect of the interaction between levels of organo-mineral fertilizer and organic matter. ** Significant at the $p<0.01$ level. * Significant at the $p<0.05$ level. NS, not significant.

Significant interaction between levels of organo-mineral fertilizer and sources of organic matter was observed at plant height at 90 DAS (Table 3). Unfolding this interaction (Table 4), allowed to observe that in the lower levels of organo-mineral fertilizer, it provided higher plant height for the two sources of organic matter, however, the filter cake obtained better response than sewage sludge in all levels.

Araújo-Neto et al. (2014), also studying the development of sorghum, verified significant interaction between types and doses of organic fertilizers at the variable of plant height.

Oliveira et al. (2016) saw that there was not interaction between the sources of organic matter and the levels of organo-mineral to plant height, stem diameter, chlorophyll a, chlorophyll b, and leaf area in sorghum at 30 DAS.

Table 4. Split of the interaction of levels $\times$ source of organic matter with respect plant height (cm) to sewage sludge (PHSS) and filter cake (PHFC) of sorghum at 90 days after sowing

\begin{tabular}{lll}
\hline Levels (\%) & PHSS & PHFC \\
\hline 70 & $43.50 \mathrm{aB}$ & $46.94 \mathrm{aA}$ \\
100 & $45.31 \mathrm{aB}$ & $48.56 \mathrm{aA}$ \\
130 & $34.81 \mathrm{cB}$ & $42.31 \mathrm{bA}$ \\
160 & $40.06 \mathrm{bB}$ & $43.94 \mathrm{bA}$ \\
\hline
\end{tabular}

Note. Means followed by same letters, uppercase in the column and lowercase in the line, are not significantly different by the Tukey's test at $p<0.05$.

For the dry mass, there was a significant interaction between the levels of organo-mineral fertilizer and the sources of organic matter (Table 3), and in its unfolding it (Table 5). The 130\% level for sewage sludge provided the highest dry mass values $(36.70 \mathrm{~g})$. However, for the filter cake, at this same level, there was a reduction in the biomass production of the plants. 
Tiritan et al. (2010) observed that the dry mass production of the aerial part of maize, that the addition of organic fertilizer next to the doses of phosphorus, allowed greater availability of the nutrient for the plants.

Table 5. Split of the interaction of levels $\times$ source of organic matter with respect dry mass $(\mathrm{g})$ to sewage sludge (DMSS) and filter cake (DMFC) of sorghum at 90 days after sowing

\begin{tabular}{lll}
\hline Levels $(\%)$ & DMSS & DMFC \\
\hline 70 & $23.42 \mathrm{cB}$ & $28.84 \mathrm{aA}$ \\
100 & $25.54 \mathrm{bcB}$ & $31.78 \mathrm{aA}$ \\
130 & $36.70 \mathrm{aA}$ & $23.97 \mathrm{bB}$ \\
160 & $29.26 \mathrm{bA}$ & $31.25 \mathrm{aA}$ \\
\hline
\end{tabular}

Note. Means followed by same letters, uppercase in the column and lowercase in the line, are not significantly different by the Tukey's test at $p<0.05$.

The in vitro digestibility of organic matter presented significant interaction between the levels of organo-mineral fertilizer and the sources of organic matter (Table 3), being from 130 and $160 \%$ of level of organo-mineral fertilizer based on sewage sludge was higher and from $70 \%$ with filter cake was smaller (Table 6). In contrast, between the source of organic matter, just in levels of 130 and $160 \%$ of filter cake obtained less values than sewage sludge.

Fertilization may influence the bromatological characteristics of plants, as well as climatic conditions. The use of sorghum in regions less suitable for maize may be an alternative for the production of silage. Martinkoski \& Vogel (2013) affirmed that sorghum with low values or without tannin, allows the in vitro digestibility of ruminants to be unaffected by these polyphenols. This maybe explains the high in vitro digestibility obtained in this work, due to the use of a sorghum without tannin.

Table 6. Split of the interaction of levels $\times$ source of organic matter with respect in vitro digestibility of organic matter (\%) to sewage sludge (IVDSS) and filter cake (IVDFC) of sorghum at 90 days after sowing

\begin{tabular}{lll}
\hline Levels $(\%)$ & IVDSS & IVDFC \\
\hline 70 & $86.24 \mathrm{bA}$ & $86.62 \mathrm{aA}$ \\
100 & $85.34 \mathrm{cA}$ & $85.72 \mathrm{bA}$ \\
130 & $87.44 \mathrm{aA}$ & $85.09 \mathrm{bB}$ \\
160 & $87.26 \mathrm{aA}$ & $85.66 \mathrm{bB}$ \\
\hline
\end{tabular}

Note. Means followed by same letters, uppercase in the column and lowercase in the line, are not significantly different by the Tukey's test at $p<0.05$.

Plant height at 30 DAS obtained adjustment in the quadratic regression equation, as shown in Figure 1. Thus, to obtain the highest plant height, of $16.02 \mathrm{~cm}$, is recommended to use just $104.16 \%$ of organo-mineral fertilizer of filter cake, or $84.75 \%$ of organo-mineral fertilizer of sewage sludge to obtain $15.53 \mathrm{~cm}$ of maximum height. The application of organo-mineral fertilizer also favored the growth of red rice (Dutra et al., 2018). 


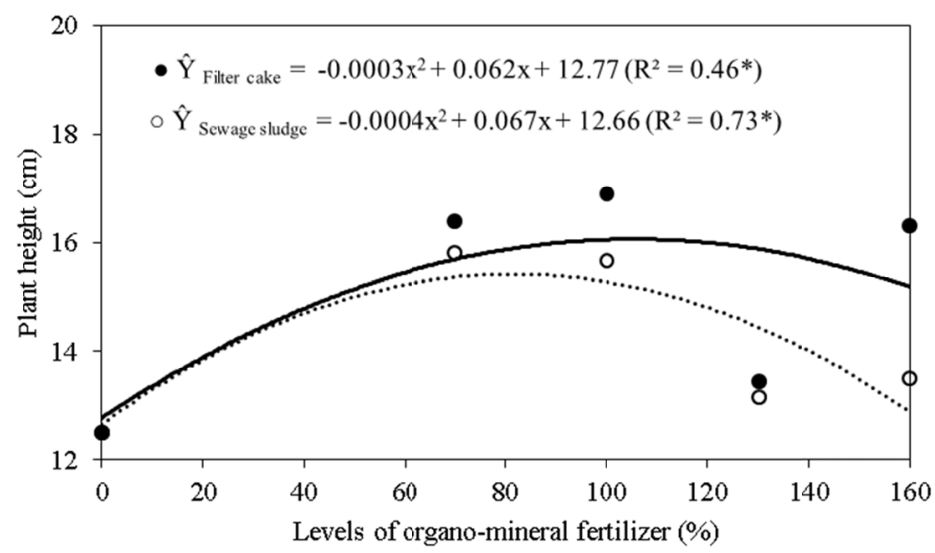

Figure 1. Plant height at 30 days after sowing of sorghum as function of sources and levels of organo-mineral fertilizer. *Significant at the $p<0.05$ level. NS, not significant

The plant height at 60 DAS showed a quadratic quadratic effect $(p>0.05)$ (Figure 2). Therefore, to obtain the highest plant height, of $31.73 \mathrm{~cm}$ and $29.46 \mathrm{~cm}$, is recommended to use $84.72 \%$ of organo-mineral fertilizer of filter cake or $93.10 \%$ of organo-mineral fertilizer of sewage sludge, respectively.

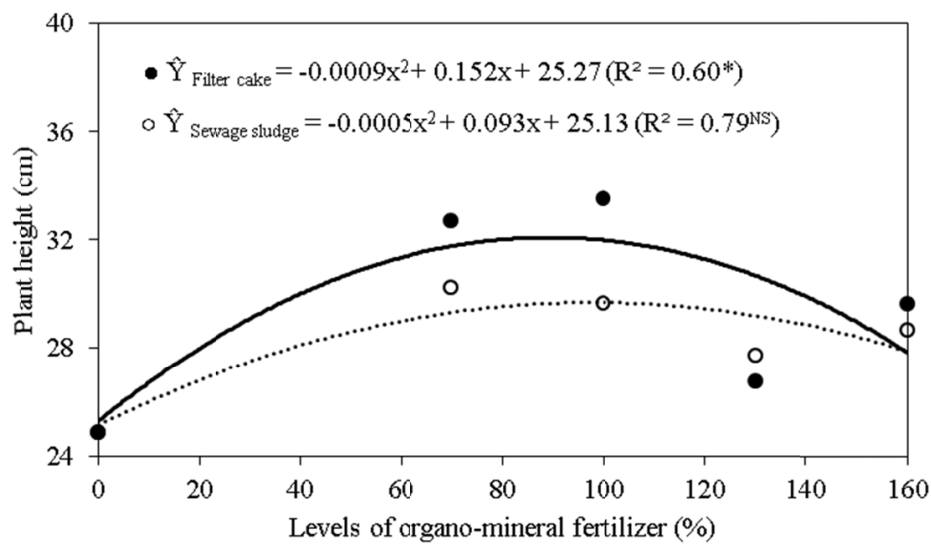

Figure 2. Plant height at 60 days after sowing of sorghum as function of sources and levels of organo-mineral fertilizer. *Significant at the $p<0.05$ level. NS, not significant

Plant height at 90 DAS obtained adjustment in the quadratic regression equation, as shown in Figure 3. Therefore, to obtain the highest plant height of $47.51 \mathrm{~cm}$ or $42.55 \mathrm{~cm}$, is recommended to use organo-mineral fertilizer in levels of $101.25 \%$ to source of filter cake and of $84.55 \%$ of of sewage sludge, respectively. 


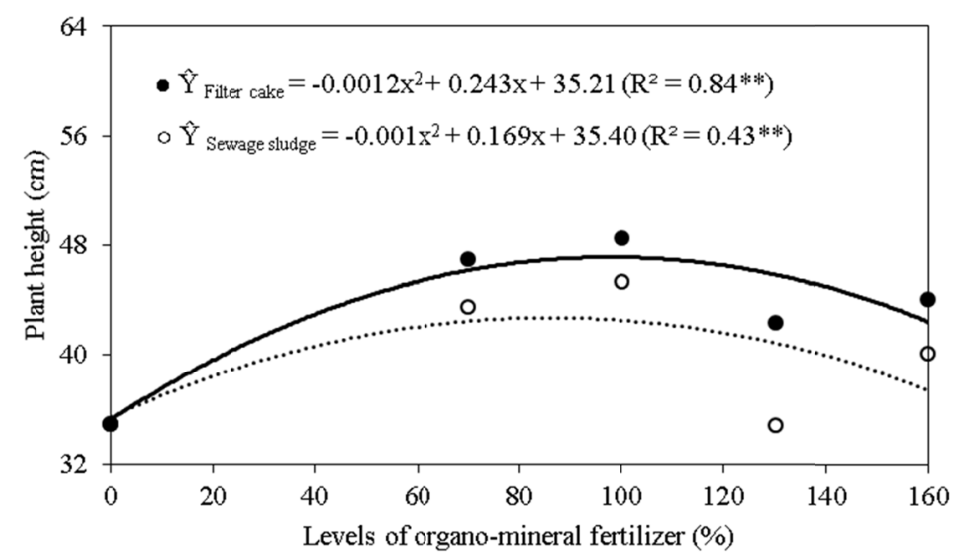

Figure 3. Plant height at 90 days after sowing of sorghum as function of sources and levels of organomineral fertilizer. ** Significant at the $p<0.01$ level. *Significant at the $p<0.05$ level

Total plant height obtained adjustment in the quadratic regression equation. Like this, to each organo-mineral fertilizer, will be obtained $66.51 \mathrm{~cm}$ of maximum total height with $113.71 \%$ of filter cake and $71.26 \mathrm{~cm}$ with $113.50 \%$ of sewage sludge.

It is important to observe for plant height, depending on the stage when the height was measured, sometimes the agromineral fertilizer from sludge is more associated with this phenotype (greater $\mathrm{R}^{2}$ ) compared to the fertilizer from filter cake, however, sometimes there is an opposite trend. That is possible because, despite complying with brazilian legislation, both products, filter cake and sewage sludge, may present different amounts of available nutrients. In addition, the absorption of nutrients is influenced by the needs required by the crop during its development.

Plant height in different days after sowing were influencied by phenological stage, when used sources of green manure in sorghum (Andrade-Neto et al., 2010).

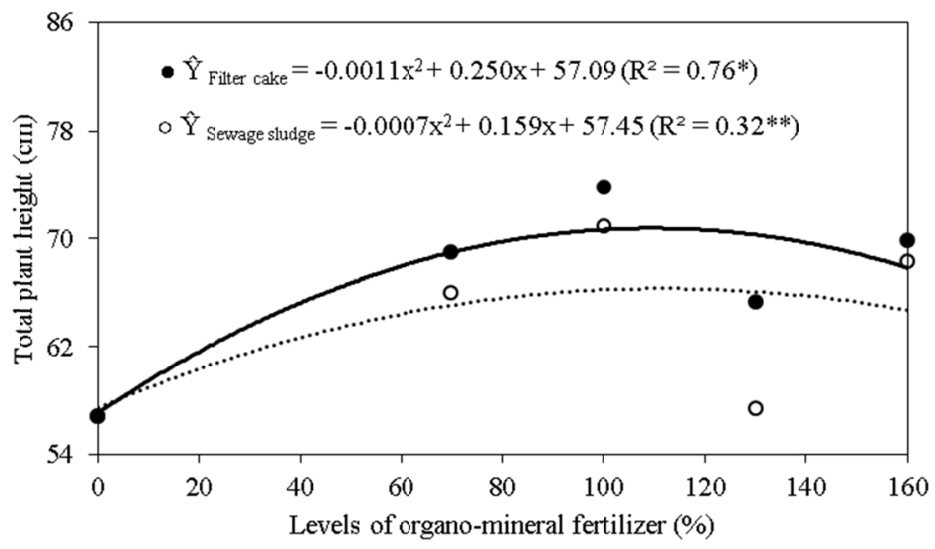

Figure 4. Total plant height of sorghum as function of sources and levels of organomineral fertilizer.

**Significant at the $p<0.01$ level. *Significant at the $p<0.05$ level

The leaf area per sheet was affected by the levels of organo-mineral fertilizer and that this effect ajusts to a polynomial quadratic model $(p<0.05)$, as shown in Figure 5. At the level $131.15 \%$ of filter cake the maximum value will be $211.55 \mathrm{~cm}^{2}$ and $110.13 \%$ of sewage sludge will be $199.87 \mathrm{~cm}^{2}$, to the organo-mineral fertilizer. Effect of levels of organo-mineral fertilizer was similar in the leaf area per plant (Figure 6), since until 130.46\% of filter cake to $2687.05 \mathrm{~cm}^{2}$ and $109.53 \%$ of sewage sludge to $1874.14 \mathrm{~cm}^{2}$. The highest value of leaf area was observed when added $20 \mathrm{t} \mathrm{ha}^{-1}$ of cattle manure in soil, corresponded an increase of $192.83 \mathrm{~cm}^{2}$ in leaf area of sorghum (Araújo-Neto et al., 2014). 


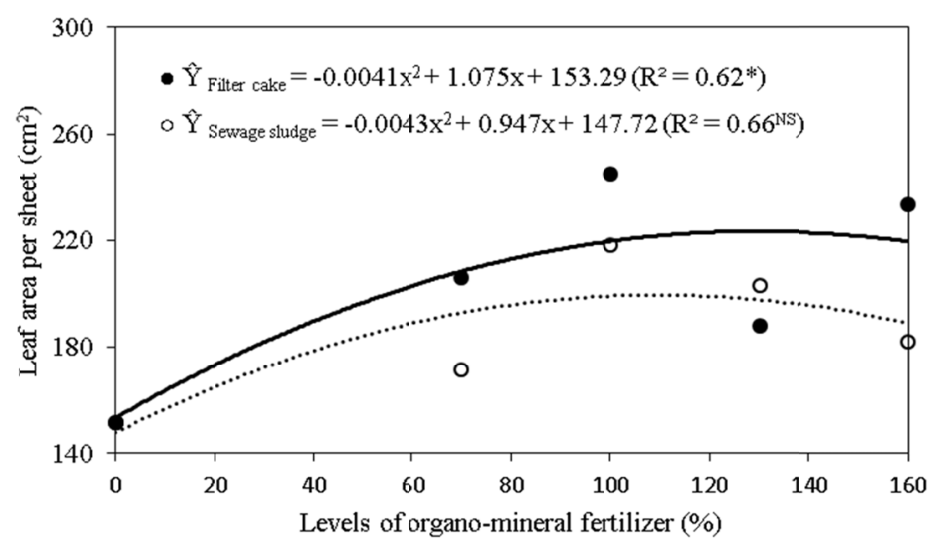

Figure 5. Leaf area per sheet of sorghum as function of sources and levels of organomineral fertilizer.

*Significant at the $p<0.05$ level. NS, not significant

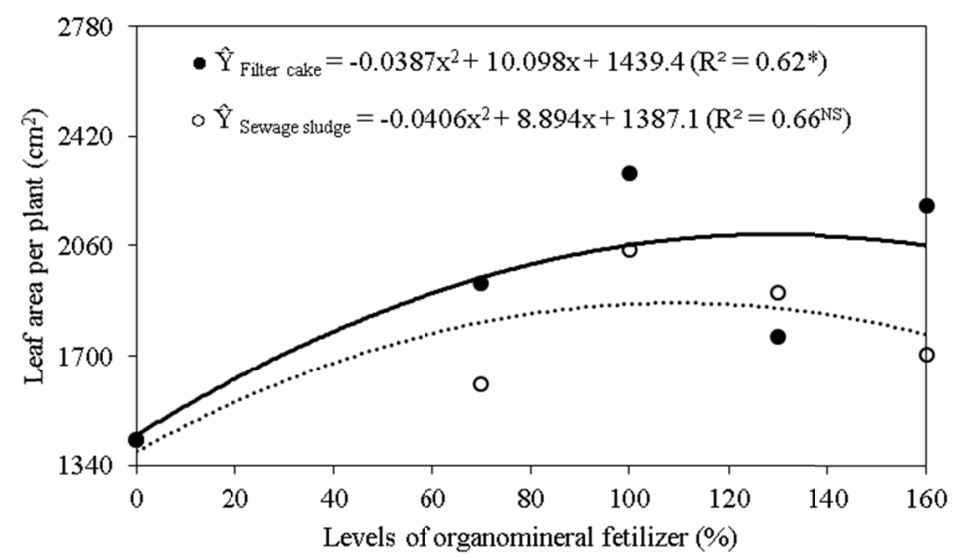

Figure 6. Leaf area per plant of sorghum as function of sources and levels of organomineral fertilizer.

*Significant at the $p<0.05$ level. NS, not significant

The production of dry mass per plant had quadratic effect on the filter cake (Figure 7), and the higher observed dry mass was of $29.86 \mathrm{~g}$ with $121.83 \%$ in the fertilization. However, the higher level of organo-mineral produced with sewage sludge, negatively affected the biomass production of the plants.

Silveira-Junior et al. (2015) verified a linear increase of dry mass of sorghum, after the application of doses of biofertlizers in the two systems of crops, in intercropping and monoculture, being that the higher dose provided similar production for both. 


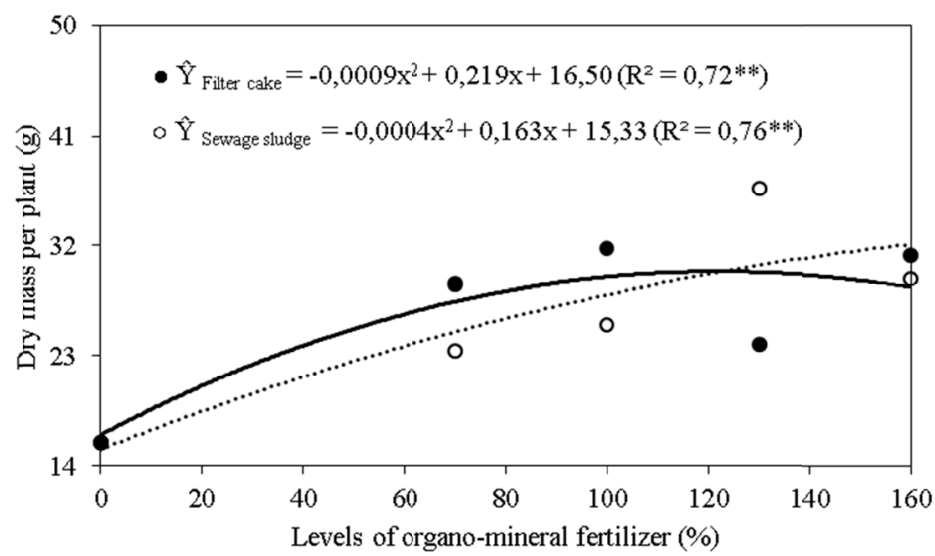

Figure 7. Dry mass per plant of sorghum as function of sources and levels of organo-mineral fertilizer. ${ }^{* *}$ Significant at the $p<0.01$ level

\section{Conclusions}

The study on the behavior of sorghum, submitted to organo-mineral fertilization, proved efficient to glimpse the effect of different organic sources composed to the product. It is important to emphasize what the producer seeks to achieve by cultivating the crop, thus achieving a more favorable result when choosing the level and the ideal fertilizer to be used. The use of organic waste is a promising source for industries and entrepreneurs, which has two correlated functions, the correct disposal of by-products and the generation of a product with added value, without presenting environmental risks. Therefore, organic waste can be sold as a source of raw material or reprocessed in the factory itself, in this case, the sewage sludge and the filter cake, potentials for plant nutrition.

\section{References}

Araújo, B. L., Arnhold, E., Oliveira-Junior, E. A., \& Lima, C. F. (2014). Genetic parameters in sorghum cultivars evaluated in the off-season. Revista Trópica-Ciências Agrárias e Biológicas, 8, 51-59.

Araújo, F. F., \& Bettiol, W. (2009). Effect of sewage sludge in soil-borne pathogens and powdery mildew severity in soybean. Summa phytopathologica, 35, 184-190. https://doi.org/10.1590/S0100-540520090 00300004

Araújo-Neto, R. A., Araújo-Filho, J. T., Silva, F. J., Rocha, A. E. Q., \& Farias, J. J. A. (2014). Forage sorghum (Sorghum bicolor 1. Moench) development submitted to different types and levels of organic fertilizer. Ciência Agricola, 12, 31-40. https://doi.org/10.28998/rca.v12i1.1278

Andrade-Neto, R. C., Miranda, N. O., Duda, G. P., Góes, G. B., \& Lima, A. S. (2010). Growth and yield of forage sorghum cv. BR 601 under green manure. Revista Brasileira de Engenharia Agrícola e Ambiental, 14, 124-130.

Barbosa, J. C., \& Maldonado, Junior, W. (2015). AgroEstat-Sistema para análises estatísticas de ensaios agronômicos (p. 396). Jaboticabal: FCAV/UNESP.

Costa, F. X., Lima, V. L. A., Beltrão, N. E. M., Azevedo, C. A. V., Soares, F. A. L., \& Alva, I. D. M. (2009). Residual effects of application of biosolid and of irrigation with wastewater on corn growth. Revista Brasileira de Engenharia Agrícola e Ambiental, 13, 687-693. https://doi.org/10.1590/S1415-43662009000 600004

Cruz, A. C., Pereira, F. S., \& Figueiredo, V. S. (2017). Organic-mineral agri-waste fertilizers: evaluation of the brazilian economic potential. Chemical Industry, 1, 137-187.

Dutra, K. O. G., Irineu, T. H. S., Véras, M. L. M., Figueredo, J. P., Silva, J. N., Andrade, R., \& Meneses, C. H. S. G. (2018). Biochemical alterations of red rice cultivated at soil water levels and organomineral fertilization. Comunicata Scientiae, 9, 185-183. https://doi.org/10.14295/cs.v9i2.2111

Embrapa (Empresa Brasileira de Pesquisa Agropecuária). (1997). Manual de métodos de análise de solos (2nd ed., p. 212). 
Kominko, H., Gorazda, K., \& Wzorek, Z. (2017). The Possibility of Organo-Mineral Fertilizer Production from Sewage Sludge. Waste Biomass Valor, 8, 1781-1791. https://doi.org/10.1007/s12649-016-9805-9

Kominko, H., Gorazda, K., Wzorek, Z., \& Wojtas, K. (2018). Sustainable Management of Sewage Sludge for the Production of Organo-Mineral Fertilizers. Waste and Biomass Valorization, 9, 1817-1826. https://doi.org/ 10.1007/s12649-017-9942-9

Martinkoski, L., \& Vogel, G. F. (2013). Using sorghum as alternative in the production of silage. Revista Verde de Agroecologia e Desenvolvimento Sustentável, 8, 177-187.

Oliveira, D. P., Camargo, R., Lemes, E. M., Lana, R. M. Q., Matos, A. L. A., \& Magela, M. L. M. (2017). Organic matter sources in the composition of pelletized organomineral fertilizers used in sorghum crops. African Journal of Agricultural Research, 12, 2574-2581. https://doi.org/10.5897/AJAR2016.11476

Pearce, R. B., Mock, J. J., \& Bailey, T. B. (1975). Rapid method for estimating leaf area per plant in maize. Crop Science, 15, 691-694. https://doi.org/10.2135/cropsci1975.0011183X001500050023x

Ribeiro, A. C., Guimarães, P. T., \& Venegaz, V. H. A. (1999). $5^{a}$ Aproximação-Recomendações para o uso de corretivos e fertilizantes em Minas Gerais (1st ed., p. 359). Viçosa-MG: Editora SBCS.

Schmidt-Filho, E., Gonçalves, J. C., Silva, M. T., Matos, N. C. S., \& Azevedo, R. E. C. (2016). Reducing the environmental impacts of the sugarcane sector using filter cake in soil fertilization. Revista Uningá, 27, 05-09.

Silveira-Junior, O., Santos, A. C., Rocha, J. M. L., Ferreira, C. L. S., Oliveira, L. B. T., Rodrigues, M. O. D., \& Rodrigues, M. O. D. (2015). Establishment of pastures under monoculture farming and integrated with biofertilizer using poultry litter as a nutrient source. Rev. Bras. Saúde Prod. Anim., 16(3), 499-512. https://doi.org/10.1590/S1519-99402015000300003

Soil Survey Staff. (2014). Keys to Soil Taxonomy (12th ed., p. 362). Washington, DC: United States Department of Agriculture-Natural Resources Conservation Service.

Teles, D. S., Oliveira, G., Mendonça, H. G., \& Cruz, P. H. L. (2016). Reverse logistics and sustainability. Journal of Innovation, Projects and Technologies, 4, 129-136.

Tilley, J. M. A., \& Terry, R. A. (1963). A two-stage technique for the "in vitro" digestion of forage crops. The Journal of the British Grassland Society, 18, 104-111. https://doi.org/10.1111/j.1365-2494.1963.tb00335.x

Tiritan, C. S., Santos, D. H., Foloni, J. S. S., \& Alves-Júnior, R. (2010). Phosphorus fertilization mineral and organomineral on corn. Colloquium Agrariae, 6, 08-14.

Tomazeli, V. N., Santos, I., \& Morales, R. G. F. (2011). Organic residues for the control of bean diseases caused by Sclerotium rolfsii. Ambiência, 7, 65-74. https://doi.org/10.5777/ambiencia.2011.01.04

Trani, P. E., Terra, M. M., Tecchio, M. A., Teixeira, L. A. J., \& Hanasiro, J. (2013). Organic Fertilization of Vegetables and Fruits. Organic fertilization of vegetables and fruits (Technical Bulletin). Retrieved from http://www.iac.sp.gov.br/imagem_informacoestecnologicas/83.pdf

\section{Copyrights}

Copyright for this article is retained by the author(s), with first publication rights granted to the journal.

This is an open-access article distributed under the terms and conditions of the Creative Commons Attribution license (http://creativecommons.org/licenses/by/4.0/). 